\title{
The Characteristic Change of Shallot (Allium ascalonicum L.) During Curing Process
}

\author{
Mohamad Djali, Selly Harnesa Putri \\ Department of Food Technology, Faculty of Agroindustrial Technology, Padjadjaran University \\ Jl Bandung-Sumedang KM 21 Bandung, Indonesia \\ E-mail:agusdjali@yahoo.com
}

\begin{abstract}
The objectives of this research were to study changes in the characteristics of shallot (Allium ascalonicum L) during curing prosess at a temperature of $45^{\circ} \mathrm{C} \pm 0,6^{\circ} \mathrm{C}$, and $\mathrm{RH} 69 \% \pm 0,4 \%$. The study was consisted of 2 stages: calibration of temperature and RH in cabinet drier and Study of physical and chemical characteristics changes of red onions during curing process at selected temperatures. Research method used was experimental method with descriptive analysis followed by regression and correlation analysis. Curing time in a cabinet dryer was varied as follows; 0 hours, 32 hours, 80 hours, 92 hours, and 104 hours. Observations were conducted at curing includes tuber water content, water content of the outer shell, VRS levels, levels of total dissolved solids, tuber hardness, neck diameter, decrease weight, color of the outer shell and sensory characteristics of the bulbs, tubers neck, and outer shell. The results showed that the curing of shallot in a cabinet dryer at a temperature $45^{\circ} \mathrm{C} \pm 0,6^{\circ} \mathrm{C}$, and $\mathrm{RH}$ $69 \% \pm 0,4 \%$ by adjusting the temperature controller on the cabinet dryer at position $47^{\circ} \mathrm{C}$ produce bulbs with a good outer skin apparance. During curing process, quality of the onion bulb was improved as indicated by increased the size of the bulb diameter, tubers hardness, levels of dissolved solids, the intensity of red color at tuber skin, levels of VRS, with a reduction in root neck diameter, and decrease water content of the outer shell. This condition was marked also by dry out the outer shell and neck bulbs. Onion dried in a cabinet dryer at a temperature of $44.5 \pm 0.6{ }^{\circ} \mathrm{C}$ and $\mathrm{RH} 59.8 \pm 0.8 \%$ for 92 hours produced tubers with the best quality during curing. Characteristics of the tuber for this treatment are : water content $79.92 \% \mathrm{~V} / \mathrm{B}$; water content of the outer shell $56.80 \% \mathrm{~V} / \mathrm{B}$; neck diameter of tuber $2: 21 \mathrm{~mm}$; tubers hardness $3.60 \mathrm{Kg} / \mathrm{m}^{2}$; tuber diameter $36.49 \mathrm{~mm}$; levels of dissolved solids 19:44\%; Sucrose, red color intensity of tuber skin (a *) 29.28, VRS $33.65 \mu$ grek / g; decreasing weight of $14.23 \%$ wb; and are characterized by dried out the outer shell and neck bulbs.
\end{abstract}

Keywords-Allium ascalinicum L.; Curing; Cabinet Dryer.

\section{INTRODUCTION}

This Shallot (Allium ascalonium has many benefit for human life, in term of its economic value as well as spices or flavoring dishes and health. Shallot harvest handling must be done immediately after harvest because these commodity are easily damaged. The early stages of post-harvest handling from shallot are curing process. [5] and [9], revealed shallot curing aims to dry out the outer shell and neck bulbs forming a kind of dry tubercle. Shallot bulbs that have been cured has a shiny and tough shell and also dry bulb neck and narrow [10] revealed, post-harvest decay is common in shallot commodity are high weight loss, shoot growth, softening of shell, root growth, decay and also mold growth. Damage generally occurs during the storage, either at the farm level purposes of seed (3-6 months) or at the household level (1 2 months) for daily consumption. According to [5] shallot bulbs damaged is not only due to poor storage conditions, but also un-perfect curing. Curing process need to be considered in order to obtain a shallot with a good quality during storage. Assessment of the adequacy of curing by shallot farmer and entrepreneurs is still done visually by looking at the changes in color and bulbs flavor, outer shell dryness and neck bulbs, neck bulbs constriction as well as drought leaves. [7] revealed the adequacy indicator from shallot curing are bulbs appear to have narrowed neck, outer shell and bulbs dry rustling sounds when rubbed together.

Until now, studies of shallot post-harvest have often focused on finding better method of curing process in a conventional manner or by mechanical ways. Meanwhile, change in the characteristics of the parts from shallot bulbs were used as indicator of curing has not been much studied. The characteristics change of shallot bulbs during curing, especially the outer shell, neck bulbs and bulbs is important to reveal, because in the principle this process aims to condition the parts, so that the shallot are not easily damage during storage. This research aims to investigate the characteristics of bulbs, outer shell, and neck diameter from 
shallot after curing. Research in shallot characteristics changes during curing process should be done in controlled condition and cabinet dryer can be used for this purposes.

\section{MATERIALS AND METHODS}

This research used shallot from Menteng cultivar with 90 days after planting. The visual characteristics from the fresh shallot are having slightly oval shape round the bulbs, the wet shell colored purple with a little red, while most of the leaves are still green with a yellow bud and drooped of the neck. This shallot obtained from the Pacet Bandung, Indonesia with an altitude from 900 meters above sea levels. The research consisted of two experimental phases (1) calibration of the temperature and Relative Humidity (RH) in the cabinet dryer, (2) changes in physical and chemical characteristics from shallot during curing at different duration and temperatures.

\section{A. Experiment phase I: Cabinet dryer calibration}

This experiment aims to determine the distribution of temperature and real RH of every shelf in the cabinet dryer at the various temperature settings, and to decide the temperature that will be used in next experiments based on sensoric characteristics. Research method used descriptive analysis of the shelf of the cabinet dryer from the top shelf and tried to respectively set the temperature at $45^{\circ} \mathrm{C}, 47^{\circ} \mathrm{C}$, and $49^{\circ} \mathrm{C}$. Responses observed at the research was temperature and $\mathrm{RH}$ distribution in the cabinet dryer shelves and sensory characteristic of cured shallot such as outer shell bulbs, neck bulbs and leaves during 32 hours

\section{B. Experiment phase II: study of changes in physical and chemical characteristics from the shallot during the curing process at suitable conditions}

This phase aims to determine the physical and chemical changes that occur in the bulbs during the curing process using a cabinet dryer with suitable operational conditions resulted from phase I. physical changes including changes in the dimension and hardness bulbs, neck bulbs shrinkage, color and moisture content from the outer shell bulb. The research method used experimental method with a descriptive analysis followed by regression and correlation analysis.

\section{RESULT AND DISCUSSION}

\section{A. Temperature calibration and $R H$ from the cabinet dryer}

The result from the $\mathrm{T}$ test to temperature and $\mathrm{RH}$ at each shelf with various temperature during 32 hours are presented in Table I. Based on the statistical analyzed, shelf location provides a real effect on temperature and $\mathrm{RH}$ from the cabinet dryer. a shelf near a heat source have a lowest temperature and further away from the heat source have the higher temperature. The result of $\mathrm{T}$ value for the temperature and $\mathrm{RH}$ in shelf 2 until 4 showed each temperature was not significantly different, it can be recommended in the next experimental phase.Sensoric observation from parts of outer bulb shell, neck bulbs and leaves from the 32 hours curing process indicating that the outer shell of shallot with $47 \pm 0.5$ ${ }^{\circ} \mathrm{C}$ is very dry and impressed as excessive heating. Sightings outer shell is better shown from $45 \pm 0.6{ }^{\circ} \mathrm{C}$, which the outer shell begins to dry and still attached with the bulbs. Meanwhile, curing process of shallot with temperature $43 \pm 0.5^{\circ} \mathrm{C}$ have a outer shell still wet and any some mucus found at the base to the center of leaf. Based on experimental phase I the next curing process with cabinet dryer conducted at the conditions listed in Table II.

\section{B. Study of changes in physical and chemical characteristics of shallot in various curing duration}

Observational data and statistical analyzed value from the moisture content, VRS value, and levels of dissolved solid of Shallot during curing process are presented in the Table III

\section{Bulbs moisture content}

Table III shows the curing process causes decreasing moisture content from shallot bulbs until 80 hours curing durations. The moisture content decreasing in the next period of drying slowed. This shows amount of water evaporated during initial drying period is greater than the next period. After the curing process lasts for 80 hours, the rate of evaporation is reduces due to the drying outer shell that inhibits evaporation process. The research resulted from [11] showed shallot bulbs with Bima Brebes cultivar at harvest have $88.97 \%$ of moisture content and after curing with vortex generator, moisture content was reduced to $83.14 \%$. Meanwhile shallot bulbs from the Kuning Rampek cultivar with tray dryer at $46 \mathrm{oC}$ for 150 minutes showed reduction of moisture content from 87.01 to $81.95 \%$ [6]. Difference of moisture content is due to differences in shallot cultivar, planting areas, soils type and soil fertility. [4] and [5] revealed formation of the outer dry layer can suppress the rate in and rate out of the water as well as bulbs protected from physical, mechanical and microbiological damages. Therefore the outer shell with 80 hours can inhibits bulbs evaporation. The conection between curing duration with moisture content from bulbs in range 0 until 104 hours based on statistical tests follow a linear regression model : $\mathrm{Y}=-0.087 \mathrm{X}+87.75$ with a correlation coefficient $(\mathrm{r})$ and determination (R2) -0.85 and 0.72 respectively.

\section{Moisture content of outer shell}

Moisture content of shallot outer shells during curing up to 104 hours of curing duration followed a linear regression models. This model has a value of $\mathrm{r}$ and $\mathrm{R} 2$ respectively 0.983 and -0.931 , with equation $\mathrm{Y}=-0.196 \mathrm{X}+76.66$. The $\mathrm{r}$ value indicated strong correlation and significant between two factors. Regression coefficient also indicate curing duration greater influence on decreasing of outer shells moisture content than bulbs.

\section{E. VRS value}

Increasing rate of VRS value from Menteng cultivar is higher than Bima Brebes cultivar at Hervelly research (2005) which curing in ventilated wood boxes and Kuning Rampek cultivar from [11] with a vortex curing respectively 0.5 and $0.03 \mu$ grek/g/hours. Elevated levels from VRS allegedly due to peptidase enzyme reaction flavor precursors (L-glutamil peptidase) that produce flavor. Connection between curing duration and VRS levels follow a linear models with equation $\mathrm{Y}=0.039 \mathrm{X}+28.34$, this regression has a correlation coefficient and determination respectively 0.79 and 0.63 
TABLE I

THE RESULT OF T TEST VALUE FROM THE TEMPERATURE AND RH IN EACH SHELF

\begin{tabular}{|c|c|c|c|c|c|c|}
\hline \multirow{3}{*}{$\begin{array}{c}\text { Shelf } \\
\text { location }\end{array}$} & \multicolumn{6}{|c|}{ The average and statistical value } \\
\hline & \multicolumn{2}{|c|}{ Setting $45^{\circ} \mathrm{C}$} & \multicolumn{2}{|c|}{ Setting $47^{\circ} \mathrm{C}$} & \multicolumn{2}{|c|}{ Setting $49^{\circ} \mathrm{C}$} \\
\hline & Temp & RH & Temp & RH & Temp & RH \\
\hline Shelf No 1 & $44,84 \pm 0,33^{\mathrm{a}}$ & $67,81 \pm 0,35^{\mathrm{a}}$ & $47,24 \pm 0,64^{\mathrm{a}}$ & $66,92 \pm 0,45^{\mathrm{a}}$ & $48,89 \pm 0,52^{\mathrm{a}}$ & $66,94 \pm 0,46^{\mathrm{a}}$ \\
\hline Shelf No 2 & $43,97 \pm 0,32^{\mathrm{b}}$ & $68,11 \pm 0,36^{\mathrm{a}}$ & $46,21 \pm 0,64^{\mathrm{b}}$ & $68,11 \pm 0,41^{\mathrm{b}}$ & $48,29 \pm 0,52^{\mathrm{b}}$ & $67,59 \pm 0,41^{\mathrm{ab}}$ \\
\hline Shelf No 3 & $43,59 \pm 0,32^{\mathrm{b}}$ & $67,95 \pm 0,33^{\mathrm{a}}$ & $45,97 \pm 0,64^{\mathrm{b}}$ & $68,30 \pm 0,43^{\mathrm{b}}$ & $48,11 \pm 0,55^{\mathrm{b}}$ & $68,41 \pm 0,41^{\text {bc }}$ \\
\hline Shelf No 4 & $43,19 \pm 0,35^{\mathrm{b}}$ & $68,41 \pm 0,34^{\mathrm{a}}$ & $45,69 \pm 0,65^{\mathrm{b}}$ & $68,60 \pm 0,42^{\mathrm{b}}$ & $47,70 \pm 0,56^{\mathrm{bc}}$ & $69,04 \pm 0,41^{\text {cd }}$ \\
\hline Shelf No 5 & $42,04 \pm 0,34^{\mathrm{c}}$ & $69,36 \pm 0,32^{\mathrm{b}}$ & $42,92 \pm 0,62^{\mathrm{c}}$ & $69,35 \pm 0,42^{\mathrm{bc}}$ & $46,66 \pm 0,55^{\mathrm{cc}}$ & $69,69 \pm 0,41^{\text {de }}$ \\
\hline Shelf No 6 & $37,84 \pm 0,34^{\mathrm{d}}$ & $71,20 \pm 0,3^{\mathrm{c}}$ & $39,18 \pm 0,6^{\mathrm{d}}$ & $70,37 \pm 0,4^{\mathrm{c}}$ & $44,73 \pm 0,5^{\mathrm{c}}$ & $70,66 \pm 0,4^{\mathrm{e}}$ \\
\hline
\end{tabular}

TABLE II

CURING PROCESS OPERATING CONDITIONS FROM SHALLOT AT VARIOUS TEMPERATURE SETTINGS

\begin{tabular}{|l|l|}
\hline \multicolumn{1}{|c|}{ PARAMETER } & \multicolumn{1}{c|}{ CONDITION } \\
\hline Temperature setting & $47^{\circ} \mathrm{C}$ \\
\hline Real temperature & $45^{\circ} \mathrm{C} \pm 0,6^{\circ} \mathrm{C}$ \\
\hline RH & $69 \% \pm 0,4 \%$ \\
\hline Material volumes & $6,0 \mathrm{Kg} /$ shelf \\
\hline Curing duration & $\begin{array}{l}32 \text { hours, 80 hours, 92 } \\
\text { hours, dan } 104 \text { hours }\end{array}$ \\
\hline
\end{tabular}

TABLE III

THE STATISTICAL ANALYZED VALUE BETWEEN CURING DURATION WITH A MOISTURE CONTENT, VRS VALUE AND DISSOLVED SOLID

\begin{tabular}{|c|c|c|c|c|}
\hline \multirow{2}{*}{$\begin{array}{c}\text { Curing } \\
\text { duration } \\
\text { (hours) }\end{array}$} & \multicolumn{2}{|c|}{ Moisture content (\% V/B) } & \multirow{2}{*}{ VRS ( $\mu$ grek/g) } & \multirow{2}{*}{ Dissolved solid (\%) } \\
\hline & bulbs & Outer shell & & \\
\hline 0 & $87,85 \pm 2,33^{\mathrm{a}}$ & $76,83 \pm 1,00^{\mathrm{a}}$ & $28,28 \pm 1,25^{\mathrm{a}}$ & $16,70 \pm 0,65^{\mathrm{a}}$ \\
\hline 32 & $84,86 \pm 2,14^{\mathrm{b}}$ & $70,21 \pm 1,32^{\mathrm{b}}$ & $29,79 \pm 0,42^{\mathrm{ab}}$ & $16,95 \pm 0,86^{\mathrm{a}}$ \\
\hline 80 & $80,56 \pm 1,36 \mathrm{c}$ & $60,82 \pm 2,43^{\mathrm{c}}$ & $30,42 \pm 0,82^{\mathrm{b}}$ & $19,19 \pm 0,51^{\mathrm{b}}$ \\
\hline 92 & $79,92 \pm 3,62^{\mathrm{c}}$ & $56,80 \pm 3,45^{\mathrm{d}}$ & $33,65 \pm 0,95^{\mathrm{c}}$ & $19,44 \pm 0,03^{\mathrm{b}}$ \\
\hline 104 & $78,62 \pm 2,42^{c}$ & $56,44 \pm 3,16^{\mathrm{d}}$ & $31,75 \pm 0,53^{\mathrm{d}}$ & $19,94 \pm 1,02^{\mathrm{b}}$ \\
\hline
\end{tabular}

Description: the average value followed by same letter are not significantly toward vertical based on $\mathrm{T}$ value with $5 \%$ significanvary test

TABLE IV

THE STATISTICAL RESULTS OF EFFECT CURING DURATION TO BULBS HARDNESS, NECK AND BULBS DIAMETER AND WEIGHT SHRINKAGE FROM THE SHALLOT

\begin{tabular}{|c|c|c|c|c|}
\hline $\begin{array}{c}\text { Curing } \\
\text { Duration } \\
(\text { hour})\end{array}$ & $\begin{array}{c}\text { Bulbs hardness } \\
\left(\mathbf{K g} / \mathbf{m}^{2}\right)\end{array}$ & $\begin{array}{c}\text { Neck diameter } \\
(\mathbf{m m})\end{array}$ & Bulbs Diameter (mm) & $\begin{array}{c}\text { Weight Shrinkage } \\
\mathbf{b b})\end{array}$ \\
\hline 0 & $2,03 \pm 0,18^{\mathrm{a}}$ & $8,11 \pm 0,26^{\mathrm{a}}$ & $35,03 \pm 0,22^{\mathrm{a}}$ & $8,32 \pm 1,19^{\mathrm{a}}$ \\
\hline 32 & $2,39 \pm 0,33^{\mathrm{a}}$ & $8,10 \pm 0,21^{\mathrm{a}}$ & $35,28 \pm 0,35^{\mathrm{a}}$ & $12,85 \pm 1,03^{\mathrm{b}}$ \\
\hline 80 & $3,06 \pm 0,82^{\mathrm{b}}$ & $4,88 \pm 0,41^{\mathrm{b}}$ & $36,19 \pm 0,77^{\mathrm{b}}$ & $14,23 \pm 1,44^{\mathrm{c}}$ \\
\hline 92 & $3,60 \pm 0,44^{\mathrm{c}}$ & $2,21 \pm 0,54^{\mathrm{c}}$ & $36,49 \pm 0,65^{\mathrm{b}}$ & $14,48 \pm 1,44^{\mathrm{c}}$ \\
\hline
\end{tabular}




\section{F. Dissolved solid}

The curing duration up to 80 hours resulted increased catabolism from long-chain compounds into short-chain compounds, thus increasing the soluble components. The correlation between curing duration and level of dissolved solid until 104 hours follow a linear regression with equation $\mathrm{Y}=0.03 \mathrm{X}+16.36$, correlation coefficient and determination respectively 0.89 and 0.79 . changes of bulbs hardness, neck and bulbs diameter, weight shrinkage during curing are presented in the Table IV.

\section{G. Bulbs Hardness}

[1] revealed the correlation between dissolved solids and hardness values of vegetable and fruits. Further [8] revealed the characteristic from hardness caused by pressure of cell contents against cell wall or Turgor pressure. [4] revealed that onion epidermal cells comprising fenol compounds that have a role in formation of crosslink from outer wall of outer shells. The correlation between curing duration with bulbs hardness in the range time from 0 until 104 hours followed the linear regression $\mathrm{Y}=0.017 \mathrm{X}+1.914$. The correlation coefficient and determination models respectively 0.86 and 0.74 .

\section{H. Neck diameter}

Thermal energy is not enough to shrink neck diameters at the beginning of curing process, the significant shrinkage just happened at 80 until 92 hours of curing. There is many water occupies the cavity between cells, during the curing process water evaporation. Occurred water losses from the cells caused the cell cavities make the volume shrinked. The correlation between curing duration with neck diameter have a quadratic models with equation $\mathrm{Y}=-$ $0.00001 \mathrm{X}^{2}+0.0022+8.159$, a correlation efficient and determination respectively -0.98 and 0.96 .

\section{Bulbs diameter}

The increasing of bulbs diameter is due to higher soluble solids content. According to [3], during onion curing occur mobilization components from leaves to roots until the leaves died. The correlation between curing duration with bulbs diameter in the range time 0 until 104 hours followed a pattern linear regression with equation $\mathrm{Y}=0.015 \mathrm{X}+34.93$, with correlation and determination coefficient respectively 0.472 and 0.69 .

\section{J. Weight losses}

The weight loss increasing occurred twice in the interval curing of 32 and 80 hours, this is due to the outer shell losses moisture contents that encloses bulbs have dried up, and the release outer shell dries from the garden. The increasing of shrinkage at 80 hours due to water evaporation, flaking dried from whole layer attached to the outer shell. Meanwhile at the defoliation for 92 hours have a role in raising dry weight of bulbs shrinkage. The correlation between curing duration with bulbs shrinkage in the range 0 until 104 hours follows a pattern of quadratic regression with equation $\mathrm{Y}=-0.001 \mathrm{X}^{2}+$ $0.278 \mathrm{X}+0.241$. the correlation coefficient and determination respectively 0.98 and 0.970 .

\section{K. Microscopic characteristics}

The calculation from cell area at $800 \mathrm{x}$ magnification with image processing method using MATLAB program are presented in the Table V

TABLE V

EFFECT OF CURING DURATION TO OUTER SHELL AREA, BULBS AND NECK OF SHALLOT

\begin{tabular}{|c|c|c|c|}
\hline \multirow{2}{*}{$\begin{array}{c}\text { Curing } \\
\text { Duration } \\
\text { (hour) }\end{array}$} & \multicolumn{3}{|c|}{ Bulbs Area (Pixel) } \\
\cline { 2 - 4 } & Outer Shell & Bulbs & Neck \\
\hline 0 & 1044686 & 208310 & 34703 \\
\hline 32 & 417272 & 176420 & 28173 \\
\hline 80 & 340131 & 49784 & 25213 \\
\hline 92 & 306716 & 25643 & 13830 \\
\hline 104 & 278446 & 22546 & No data \\
\hline
\end{tabular}

Curing processing resulted shrinkage of tissue, cell shrinkage due to moisture discharge from cell thereby reducing cell volume. The neck bulbs tissue has a thick epidermis layer. The microscopic analysis followed by area calculation from neck bulbs tissue showed decreasing area of the bulb during the curing process. Shrinkage from neck area tissue due to cell evaporation, so that shrinkage a cell volume. Depreciation area also occur in the shallot endodermis.

\section{Shallot sensory description}

1) Outer bulbs shell: At harvesting, the outer shell is attached to the wet bulbs and dry coated layer is carried from the garden, a little purplish pink color, smooth texture. The leaves are green, yellow shoot, tough leaf texture, and slightly wilting bud. The wet bulb neck, strong and has not shrunk. The outer shell in the beginning of curing process still looked wet and covered with dried patches. Starting at 32 hours, the outer shell looked dry, dry layer attached to the outer shell start to break apart and some from the bulbs. Curing time at 80 hours, whole dry layer attached to the bulbs were broken apart outer shell, smooth outer shell attached to bulb. Dry defoliation occurred at 92 hour, at curing time 104 hours the outer shell loosened, the majority turned wrinkles. This shows that curing time more than 92 hours with this method is not recommended, because causes damaged to the outer shell.

2) Neck bulbs and leaves: In the general condition, more longer the curing process made more dried the neck bulbs and shriveled. This is in accordance with the result from neck bulbs diameter that up to 104 hours, neck bulb shrank by $78.47 \%$. drying and shrinkage from the neck bulbs begin to appear at 32 hours curing time. The shrinking neck bulbs with the results of previous studies was illustrated in figure 1 . Shallot leaf dolor can be maintained for relatively curing. The leaves change color from green and wet in the early hours and dry at the 80, 92, and 104 hours curing. This condition is very different from the color change of bulbs during curing by some drying 


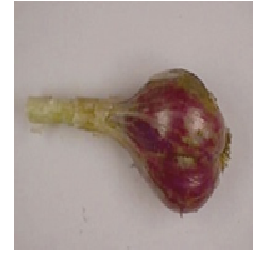

O hour curing

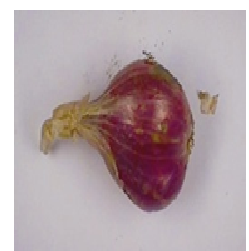

36 hours curing

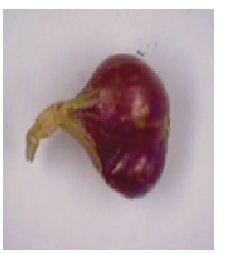

72 hours curing
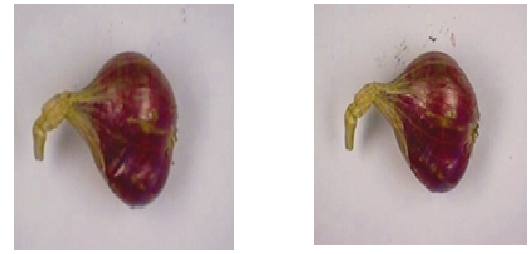

84 hours curing

96 hours curing

Fig. 1 Figure1. visualization of depreciation from the shallot neck bulbs

Curing by drying in the sun might cause dry leafs color change from green to yellow, while curing with cabinet dryer, the color can be preserved even with some dried level of leaves dried leaves together, this phenomenon suggests that the inhibition of chlorophyll degradation by the curing process. According to [13], chlorophyll degradation caused by enzyme activity of cholorophylase, by curing at temperature and $\mathrm{RH} \quad 43.7-45{ }^{\circ} \mathrm{C}$ and $58.1-60.6 \%$, respectively is might inhibit the enzyme activity so that it maintain the leaf color still green up till the end of curing process.

\section{IV.CONCLUSIONS}

Shallot curing with cabinet dryer at the temperature of $45 \pm 0.6{ }^{\circ} \mathrm{C}$ and $\mathrm{RH} 69 \pm 0.4 \%$ produces bulbs with a good appearance of the outer shell bulb of shallot, During the curing process, there might occur an improvement of shallot bulb by increasing a diameter bulbs, bulbs hardness, levels of dissolved solid, level of VRS, neck downsizing diameter, and decreasing moisture content of the outer shell. Shallot with 92 hours curing time produces the best quality bulbs.

\section{REFERENCES}

[1] Atherton, J.G, and G.P. Harris. 1986. The Tomato Crop Champion and Hall Ltd., New York. Dalam: U. Sumpena (Ed) 1995. Hubungan Jumlah Buah Perpohon dengan Kuantitas dan Kualitas Hasil pada Tomat (Lycopersicon esculentum Mill).

[2] Prosiding Seminar Ilmiah Nasional Komoditas Sayuran. Balai Penelitian Tanaman Sayuran (Balitsa), Lembang, Bandung.

[3] Currah, F. and F.J. Proctor. 1990. Onion in Tropical Regions. Natural Resources Institute Bulletin. 12(35): 65-70.

[4] Gubb, I.R. and H.S. MacTavish. 2002. Onion Pre-and Postharvest Considerations. Fresh Produce Consultancy, Mulberry Lodge Culmstocs, Cullompton, Devon, UK.

[5] Kader, A.A. 1992. Postharvest Biology and Technology: An Overview. In Kader, A.A. (ed). Postharvest Technology of Horticultural Crops. University of California, Oakland, CA.

[6] Marsetio, 1998. Pengaruh Suhu dan Kecepatan Aliran udara Pengering terhadap Kualitas dan Umur Simpan Bawang Merah Kultivar "Kuning Rampek". Tesis Magister Pertanian. Program Pascasarjana, Universitas Padjadjaran.

[7] Musaddad D. dan R.M. Sinaga. 1995. Pengaruh Suhu Penyimpanan terhadap Mutu Bawang Merah (Allium ascalonicum L.). Bull. Penel. Hort. 26(2) : 134-141.

[8] Pantastico, Er.B.,H.Subramanyam, M.B.Bhatti, N.Ali, dan E.K.Akamine. 1986. Dalam Pantastico, Er.B. Fisiologi Pascapanen,
Penanganan dan Pemanfaatan Buah-buahan dan Sayur-sayuran Tropika dan Subtropika. Bab 4, hal 91. Penerjemah: Kamaryani. Penerbit Gadjahmada University Press, Yogyakarta.

[9] Rubatzky, V.E. and M. Yamaguchi. 1997. Sayuran Dunia 2. Prinsip, Produksi, dan Gizi. Penerbit Institut Teknologi Bandung, Bandung.

[10] Ryall, A.L. and W.J. Lipton., 1984. Handling, Transportation and Storage of Fruits and Vegetables. Volume I. AVI Publishing Co., Westport, Connecticut.

[11] Sinaga, R.M.dan A.Asgar. 1992. Pengeringan Bawang dengan Pengering Vorteks. Bul. Penelitian Hortikultura 19(4): 63 - 70.

[12] Susetyo, D.C. 1991. Studi Pengeringan Bawang Merah (Allium ascalonicum L.) dengan Menggunakan Ruang Berpembangkit Vorteks. Skripsi Fakultas Teknologi Pertanian IPB, Bogor.

[13] Tranggono. 1989. Teknologi Pasca Panen. PAU Pangan dan Gizi UGM. Yogyakarta. 